\title{
THE BMP2 VARIANT L51P RESTORES THE OSTEOGENIC DIFFERENTIATION OF HUMAN MESENCHYMAL STROMAL CELLS IN THE PRESENCE OF INTERVERTEBRAL DISC CELLS
}

\author{
A. Tekari', R.D. May', D.A. Frauchiger ${ }^{1}$, S.C.W. Chan ${ }^{2}$, L.M. Benneker ${ }^{3}$ and B. Gantenbein ${ }^{1 *}$ \\ ${ }^{1}$ Tissue and Organ Mechanobiology, Institute for Surgical Technology and Biomechanics, Medical Faculty, \\ University of Bern, Bern, Switzerland \\ ${ }^{2}$ Biointerfaces, Empa, Swiss Federal Laboratories for Materials Science and Technology, St. Gallen, Switzerland \\ ${ }^{3}$ Department of Orthopaedic Surgery and Traumatology, Inselspital, Bern University Hospital, \\ University of Bern, Bern, Switzerland
}

\begin{abstract}
Spinal fusion is hampered by the presence of remaining intervertebral disc (IVD) tissue and leads to spinal nonunion. While the exact mechanism remains unknown, we hypothesise that factors preventing disc ossification, such as antagonists of the bone morphogenetic proteins (BMP), could be responsible for this process.

The objective of this study was to investigate spinal non-union using an in vitro human model with a focus on the BMP signalling components and to identify factors contributing to the incomplete and delayed ossification. Human bone marrow-derived mesenchymal stromal cells (MSC) were cocultured with IVD cells in the presence of L51P, a BMP2 variant with osteoinductive potential. The ossification of MSC was evaluated by quantitative reverse transcription polymerase chain reaction (qPCR), alkaline phosphatase (ALP) activity and alizarin red staining. Endogenous expression of major BMP antagonists, namely Gremlin (GREM1), Noggin (NOG) and Chordin (CHRD) was detected in IVD-derived cells, with abundance in nucleus pulposus cells. Osteogenesis of MSC was hindered by IVD cells as shown by reduced alizarin red staining, ALP activity and qPCR. L51P, added to the cocultures, restored mineralisation, blocking the activity of the BMP antagonists secreted by IVD cells.

It is possible that the BMP antagonists secreted by IVD cells are responsible for spinal non-unions. The inhibition of BMP antagonists with L51P may result in an efficient and more physiological osteoinduction rather than delivery of exogenous osteogenic factors. Therefore, L51P might represent an attractive therapeutic candidate for bone healing.
\end{abstract}

Keywords: Spinal fusion, intervertebral disc, stem cells, coculture, osteogenesis, bone morphogenetic proteins, antagonists of bone morphogenetic proteins, BMP2 variant L51P.

\author{
*Address for correspondence: \\ Benjamin Gantenbein, Prof. Dr \\ Tissue and Organ Mechanobiology, Institute for Surgical \\ Technology and Biomechanics \\ Stauffacherstrasse 78 \\ 3014 Bern, Switzerland
}

Telephone: +41316315951

Email: Benjamin.Gantenbein@istb.unibe.ch

\section{Introduction}

The intervertebral disc (IVD) is an avascular tissue with nearly absent self-healing potential. Disc degeneration represents a major cause of chronic back pain and is associated with economic and social burdens (Balagué et al., 2012; Hoy et al., 2014; Dagenais et al., 2008). At some stage of their life, back pain has affected about $80 \%$ of adults' population. Current surgical treatments aim to repair the damaged disc replacing the injured tissue with a functional biological substitute, prosthesis or with fusion of the painful segments. Spinal interbody fusion is a surgical technique used to join two or more vertebral bodies replacing the IVD tissue with a cage filled with a bone autograft or allograft or a bone substitute, generally with the support of osteoinductive growth factors. Primary stability is achieved with the use of pedicle screw-based instrumentation, lateral or anterior plating systems, or direct fixation with screws, anchored within the cage. While the feasibility and benefits of interbody fusion have been recognised, removal of disc tissue is time consuming and, especially in case of minimally invasive surgical techniques, is often incomplete (Watkins et al., 2014).

It has been suggested that partial removal of the disc results in a delayed and incomplete spinal fusion, requiring therefore reoperation (Osterman et al., 2003; Malter et al., 1998; Watkins et al., 2014). From a clinical observation, the presence of nucleus pulposus (NP) tissue seems to alter the ossification process (McAfee et al., 2002) and a spinal non-union was reported in up to $20-40 \%$ of the cases (Turner et al., 1992; Lee et al., 2011). Li et al. (2002) reported a delayed fusion of the spine of a porcine animal model in the presence of NP tissue within the disc space after spinal fusion surgery. However, the exact mechanism by which IVD cells and tissues hinder the ossification of the spine remains unknown.

The IVD is composed of an inner NP surrounded by the annulus fibrosus (AF) tissue and hyaline-like articular cartilage is located at the endplates between the IVD and the vertebral bodies. Bone morphogenetic proteins (BMP) signalling is required for spinal and joint formation and alteration within this pathway results in skeletal diseases (Yanagita, 2005; Salazar et al., 2016). BMP signalling molecules, originally discovered for their ability to induce bone and cartilage formation, contribute to the development of various tissues during embryonic determination and adult tissue homeostasis, such as maintenance of joint integrity and repair of long bone fractures (Tsuji et al., 2006). 
BMP signalling molecules belong to the transforming growth factor $\beta$ (TGF $\beta$ ) superfamily. Ligands of the BMP initiate specific signalling cascades binding the cell surface receptors type I and type II BMP serine/ threonine kinase receptors (BMPR1 and BMPR2). Within the heterotetrameric formed complex, BMPR2 phosphorylates BMPR 1 and the signal is propagated by phosphorylation of the transcription factor SMAD1 (SMA and mothers against decapentaplegic homolog 1), SMAD5 and SMAD8 (Rahman et al., 2015). BMP signal transduction is tightly regulated by intracellular mediators and extracellular binding proteins, recognised as BMP antagonists. These antagonists function through direct association with BMP ligands, thus prohibiting BMP from binding their cognate receptors (Walsh et al., 2010). BMP antagonists, including Noggin (NOG), Chordin (CHRD) and the DAN (differential screeningselected gene aberrative in neuroblastoma) family play a pivotal role in skeletogenesis and maintenance of adult tissue homeostasis (Stafford et al., 2011; Wijgerde et al., 2005; Wu et al., 2016). For instance, it has been shown that NOG is an essential mediator for joint formation and NOG-mediated antagonism of BMP signalling is required for normal patterning (McMahon et al., 1998). While the importance of the BMP signalling molecules in axial skeleton development was previously reported, little is known about their contribution in adult IVD homeostasis. Thus, in order to improve spinal fusion surgery, it is important to investigate the role of BMP antagonists that are likely produced by IVD cells and might regulate bone formation and differentiation potential of mesenchymal stem cells to osteoprogenitor cells. For instance, the expression of BMP antagonists is increased during fracture healing and distraction osteogenesis (Kloen et al., 2012; Dean et al., 2010; Haque et al., 2008). Similarly, it is hypothesised that BMP antagonists, such as NOG and DAN family, are responsible for the reported spinal nonunion, although recombinant human BMP2 (rhBMP2) and
rhBMP7 are administered in the orthopaedics in very high doses (Govender et al., 2002; Friedlaender et al., 2001; Haid et al., 2004) probably to compensate for the inhibitory activity of the BMP antagonists. In a clinical setting, inactivating these antagonists may represent a better therapeutic option to enhance bone regeneration, rather than the administration of excessive and non-physiological concentrations of BMPs that also raises safety issues (Carragee et al., 2012). The synthesis of an engineered BMP2 variant called L51P with a substitution of leucine to proline at codon position 51 was previously reported (Keller et al., 2004). L51P is deficient in type I receptor binding, whereas it maintains its affinity binding to type II receptors and modular proteins including NOG, CHRD and DAN family. These modifications convert the BMP2 variant L51P into a receptor-inactive inhibitor of BMP antagonists. Importantly, L51P blocks the inhibitory action of endogenously expressed BMP antagonists, such as NOG, increases binding of BMP ligands to BMP receptors and restores the induction of osteogenesis. For instance, inhibition of endogenously expressed BMP antagonists with L51P increases bone healing in a rat femoral defect and reduces the demand for exogenous BMP2 (Sebald et al., 2012).

Recently, we showed in an in vitro coculture system for spinal fusion that IVD cells inhibit the osteogenic differentiation potential of bone marrowderived mesenchymal stromal cells (MSC) (Chan et al., 2015). Within this study, we aimed to understand the contribution of possibly involved BMP signalling pathways during ossification, with a focus on BMP antagonists. We determined the endogenous expression levels of the major BMP antagonists in IVD cells. Then, we assessed the effect of measured levels of BMP antagonists on osteogenesis. Subsequently, we investigated whether L51P-mediated neutralisation of BMP antagonists might improve the ossification of human osteoblasts precursor cells in the presence of IVD cells in a novel coculture

Table 1.Patients donor list of bone marrow aspirates and intervertebral disc (IVD) tissues for the coculture experiments. The bone marrow aspirates were obtained from 8 vertebral bodies of patients aged $48 \pm 24.8$ years $($ mean $\pm \mathrm{SD}$ ) and 8 IVD tissues were collected from patients aged $47 \pm 10.4$ (mean $\pm \mathrm{SD}$ ). f female, $\mathrm{m}$ male, L lumbar vertebrae, S sacral, T trauma, SD symptomatic degenerative disc, TD trauma degenerative.

\begin{tabular}{|c|c|c|c|c|c|c|c|c|}
\hline \multicolumn{4}{|c|}{ Bone marrow aspirates } & \multicolumn{4}{|c|}{ IVD tissues } & \multirow[b]{2}{*}{ Type } \\
\hline $\begin{array}{l}\text { Coculture } \\
\text { experiment }\end{array}$ & \begin{tabular}{|l} 
MSC \\
donor
\end{tabular} & \begin{tabular}{|l|}
$\begin{array}{l}\text { Patient } \\
\text { birth }\end{array}$ \\
\end{tabular} & Sex & $\begin{array}{l}\text { IVD } \\
\text { donor }\end{array}$ & Level & $\begin{array}{l}\text { Patient } \\
\text { birth }\end{array}$ & Sex & \\
\hline 1 & 1 & 1931 & $\mathrm{f}$ & 1 & L1-L2 & 1968 & $\mathrm{~m}$ & $\mathrm{~T}$ \\
\hline 2 & 2 & 1995 & $\mathrm{~m}$ & 2 & L4-L5 & 1959 & $\mathrm{~m}$ & SD \\
\hline 3 & 2 & 1995 & $\mathrm{~m}$ & 3 & L1-L2 & 1982 & $\mathrm{~m}$ & $\mathrm{SD}$ \\
\hline 4 & 3 & 1986 & $\mathrm{f}$ & 4 & L5-S1 & 1958 & $\mathrm{~m}$ & $\mathrm{~T}$ \\
\hline 5 & 4 & 1958 & $\mathrm{~m}$ & 5 & L1-L2 & 1975 & $\mathrm{~m}$ & TD \\
\hline 6 & 4 & 1958 & $\mathrm{~m}$ & 6 & L3-L4 & 1957 & $\mathrm{f}$ & TD \\
\hline 7 & 5 & 1957 & $\mathrm{f}$ & 7 & L1-L2 & 1975 & $\mathrm{~m}$ & TD \\
\hline 8 & 5 & 1957 & $\mathrm{f}$ & 8 & L3-L4 & 1957 & $\mathrm{f}$ & TD \\
\hline
\end{tabular}




\begin{tabular}{|l|l|l|l|l|}
\hline IVD donor & Level & Patient birth & Sex & Type \\
\hline 1 & L4-L5 & 1959 & $\mathrm{~m}$ & SD \\
\hline 2 & T12-L1 & 1968 & $\mathrm{~m}$ & TD \\
\hline 3 & L1-L2 & 1968 & $\mathrm{~m}$ & TD \\
\hline 4 & T12-L1 & 1982 & $\mathrm{~m}$ & TD \\
\hline 5 & L5-S1 & 1958 & $\mathrm{~m}$ & TD \\
\hline 6 & L2-L3 & 1997 & $\mathrm{f}$ & TD \\
\hline 7 & T12-L1 & 1992 & $\mathrm{f}$ & TD \\
\hline 8 & T12-L1 & 1956 & $\mathrm{f}$ & TD \\
\hline 9 & L4-L5 & 1966 & $\mathrm{f}$ & SD \\
\hline 10 & T12-L1 & 1999 & $\mathrm{~m}$ & TD \\
\hline 11 & L2-L3 & 2001 & $\mathrm{~m}$ & TD \\
\hline 12 & L3-L4 & 1979 & $\mathrm{~m}$ & TD \\
\hline 13 & L2-L3 & 1966 & $\mathrm{~m}$ & TD \\
\hline 14 & C6-C7 & 1977 & $\mathrm{f}$ & SD \\
\hline 15 & L1-L2 & 1997 & $\mathrm{~m}$ & T \\
\hline 16 & T12-L1 & 1999 & $\mathrm{~m}$ & T \\
\hline
\end{tabular}

Table 2. Patients donor list of intervertebral disc (IVD) tissues for the determination of BMP antagonists. The bone marrow aspirates were obtained from 16 IVD tissues from patients aged $39 \pm 16.6$ years (mean $\pm \mathrm{SD})$. f female, $\mathrm{m}$ male, L lumbar vertebrae, $\mathrm{S}$ sacral, T thoracic, C cervical, $\mathrm{T}$ trauma, SD symptomatic degenerative disc, TD trauma degenerative. system. Understanding the contribution of BMP signalling components to bone regeneration of the spine is of a central importance as it may provide therapeutical targets for an improved spinal fusion.

\section{Materials and Methods}

\section{Human materials}

Human bone marrow aspirates and IVD tissues were collected from patients undergoing spinal fusion surgery. The procedure was performed with patient's written consent and the synopsis was approved by the ethical committee of the canton of Bern. The disc materials were harvested from patients undergoing surgery for painful, degenerated discs ( $\mathrm{SD}, n=2)$, trauma patients with healthy discs (T, $n=2)$ and degenerated non-symptomatic trauma discs (TD, $n=4)$ for the coculture experiments (Table 1). 16 additional human discs $(\mathrm{SD}=3 ; \mathrm{T}=2$ and $\mathrm{TD}=11)$ were used for the determination of expression of IVD endogenous BMP antagonists by gene expression analysis, immunocytochemistry, flow cytometry and conditioned media analysis (Table 2).

\section{Cell isolation}

Mononuclear cell fractions from bone marrow samples were isolated by gradient centrifugation (Histopaque 1077, Sigma-Aldrich, Buchs, Switzerland) and then seeded in basal medium consisting of Alpha minimum Essential Medium ( $\alpha$-MEM) containing $10 \%$ foetal bovine serum (FBS, Sigma-Aldrich), penicillin/streptomycin (P/S, $100 \mathrm{U} / \mathrm{mL}$ and $100 \mu \mathrm{g} / \mathrm{mL}$, respectively, Merck, Darmstadt, Germany) and $2.5 \mathrm{ng} / \mathrm{mL}$ fibroblast growth factor 2
(FGF2, Peprotech, London, UK) (Solchaga et al., 2005). The MSC were expanded in monolayer cultures for up to three passages, in order to purify the cell population and increase their yield. Cells were cryopreserved at $-150{ }^{\circ} \mathrm{C}$ for further experiments. IVD tissue samples were divided into AF and NP by an experienced surgeon and processed within $24 \mathrm{~h}$ after the surgery. Disc-derived cells were isolated by sequential digestion of IVD tissues with $1.9 \mathrm{mg} / \mathrm{mL}$ pronase (Roche, Basel, Switzerland) for $1 \mathrm{~h}$ and collagenase II (64 U/mL for NP and $129 \mathrm{U} / \mathrm{mL}$ for AF, Worthington, London, UK) at $37{ }^{\circ} \mathrm{C}$ overnight on a plate shaker (Lee et al., 2015). The remaining undigested tissue debris was removed by filtration through $100 \mu \mathrm{m}$ strainer (Falcon, Becton Dickinson, Allschwil, Switzerland) and subsequently the cell viability was determined by trypan blue exclusion. The IVD cells were expanded in a proliferation medium (Dulbecco's Modified Eagle Medium [DMEM] containing $10 \% \mathrm{FBS}$ and $\mathrm{P} / \mathrm{S}$ ) until confluency and processed for the coculture experiments.

\section{Cell and alginate coculture}

MSC were seeded at a density of $20 \times 10^{3}$ cells/well in 12 -well plates in the basal medium and left overnight for cell adherence. AF cells (AFC) and NP cells (NPC) were mixed separately in $1.2 \%$ alginate solution (Fluka, Basel, Switzerland) at a density of 4 millions $/ \mathrm{mL}$. The suspensions were dropped through a $22-\mathrm{G}$ needle into a $102 \mathrm{mM} \mathrm{CaCl}_{2}$ and $0.9 \% \mathrm{NaCl}$ to form the alginate beads ( $\sim 25 \mu \mathrm{L}$ droplets). The alginate beads ( 6 beads/well) were transferred to indirect culture inserts $(0.4 \mu \mathrm{m}$ pore size, Becton Dickinson, Brussels, Belgium) with previously seeded MSC and the cultures were conducted in osteogenic medium ( $\alpha$-MEM containing $10 \% \mathrm{FBS}, \mathrm{P} / \mathrm{S}, 100 \mathrm{nM}$ 
dexamethasone, $10 \mathrm{mM} \beta$-glycerophosphate and $0.05 \mathrm{mM}$ L-ascorbic acid-2-phosphate [all from Sigma-Aldrich]). In parallel, the same experimental set-up was conducted with the addition of L51P $(100 \mathrm{ng} / \mathrm{mL}$, synthesised and purified at the Department of Physiological Chemistry, University of Würzburg, Germany) to the cultures. Positive control group represented MSC coculture with empty alginate beads in osteogenic medium. MSC cultured in basal medium served as negative control group (Fig. 1). The control and experimental groups were maintained in culture for $21 \mathrm{~d}$ with medium refreshed twice a week.

\section{Analysis of gene expression}

Total RNA was extracted as previously described (May et al., 2017) from MSC after coculture and bone-related genes, including alkaline phosphatase (ALP), runtrelated transcription factor 2 (RUNX2), alpha-2 chain of collagen type I (COL1A2), osteopontin (OPN), osteocalcin (official name is bone gamma-carboxyglutamic acidcontaining protein, BGLAP) and the ribosomal 18S RNA as reference gene, were determined. The average cycle number of $18 \mathrm{~S}$ accounted for $12.1 \pm 0.49$ (mean \pm standard deviation [SD]) among individual treatment groups. Glyceraldehyde 3-phosphate dehydrogenase (GAPDH) was monitored as a second reference gene and accounted for $16.7 \pm 0.63$ (mean \pm SD) cycles. The expression of BMP antagonists, including GREM1, NOG and CHRD was determined in passage one AFC and NPC. Human-specific oligonucleotide primers (Table 3) (Microsynth, Balgach, Switzerland) were designed with Beacon Designer ${ }^{\mathrm{TM}}$ software (Premier Biosoft, California, Palo Alto, USA) based on nucleotide sequences from GenBank. The primers were tested for efficiency and melting curves of amplicons were performed to determine specific amplification.
Relative gene expression was determined by application of a threshold cycle and normalised to control MSC on day 0 using the $2^{-\Delta \Delta \mathrm{Ct}}$ method according to Livak and Schmittgen (Livak and Schmittgen, 2001).

\section{Flow cytometry}

To assess intracellular BMP antagonists, IVD cells from passage one were permeabilised as previously described (Flagler et al., 2009). Briefly, $20 \times 10^{3}$ cells in $100 \mu \mathrm{L}$ of phosphate buffered saline (PBS) $+2 \%$ FBS were mixed with $1 \mathrm{~mL}$ ice cold methanol $\left(-20^{\circ} \mathrm{C}\right)$ and incubated for 15 min on ice. After washing, the cells were incubated with a mouse anti-human NOG $(1 \mu \mathrm{g} / \mathrm{mL}$, clone $1 \mathrm{H} 8$, SigmaAldrich), rabbit anti-human GREM1 (1 $\mu \mathrm{g} / \mathrm{mL}, \mathrm{sc}-28873$, Santa Cruz, Dallas, TX, USA) and goat anti-human CHRD ( $1 \mu \mathrm{g} / \mathrm{mL}$, sc-18265, Santa Cruz) antibodies for $15 \mathrm{~min}$ at room temperature. Incubation for further $15 \mathrm{~min}$ with the appropriate secondary antibodies was conducted for detection of antibody binding. NOG antibody was labelled with the Alexa Fluor 555 goat anti-mouse, GREM1 with the Alexa Fluor 488 goat anti-rabbit and CHRD with the Alexa Fluor 555 rabbit anti-goat $(10 \mu \mathrm{g} / \mathrm{mL}$, all from Thermo Fisher Scientific, Basel, Switzerland, Table 4). Isotype-matched antibodies (Thermo Fisher Scientific) were used as negative controls. Fluorescence was measured on a LSRII flow cytometry system (Becton Dickinson) and the data were analysed using FlowJo Software (version 10.1 for MacOS X; LLC, Ashland, OR, USA).

\section{Immunocytochemistry}

AFC and NPC from passage one were seeded on coverslips in 6-well plates at a density of $50 \times 10^{3}$ cells/well in the proliferation medium. The cells were harvested after $48 \mathrm{~h}$, fixed with $4 \%$ formaldehyde solution for $10 \mathrm{~min}$

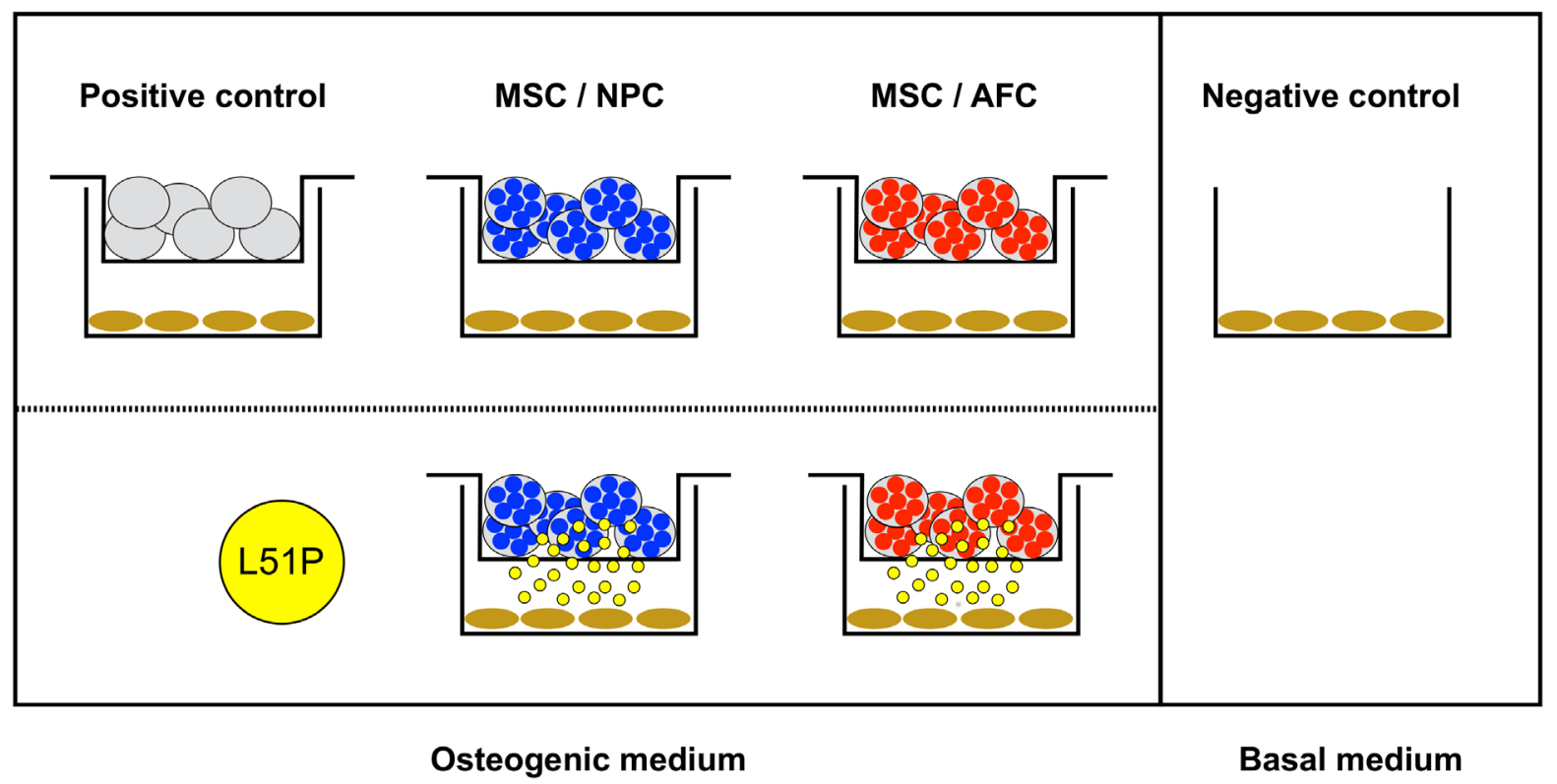

Fig. 1. Experimental design for the coculture experiments. Human bone marrow-derived mesenchymal stromal cells (MSC) were seeded in 12-well plates and cultured using indirect coculture inserts with nucleus pulposus cells (NPC) and annulus fibrosus cells (AFC) embedded in alginate beads supplemented with medium containing osteogenic factors. The experimental setup was replicated by addition of L51P $(100 \mathrm{ng} / \mathrm{mL})$ to the cocultures. Positive control group represents MSC cultured with empty alginate beads in medium containing osteogenic factors and negative control group was MSC cultured in basal medium (without osteogenic factors). 
Table 3. Custom-designed human DNA primers used for real-time qPCR study. Amplicons were generated using a 2-step amplification cycling $\left(95^{\circ} \mathrm{C}\right.$ for $15 \mathrm{~s}$ and $61^{\circ} \mathrm{C}$ for $30 \mathrm{~s}$ for 45 cycles) and SYBR-green mastermix.

\begin{tabular}{|l|l|l|}
\hline Gene & Forward sequence & Reverse sequence \\
\hline 18 S & CGA TGC GGC GGC GTT ATT C & TCT GTC AAT CCT GTC CGT GTC C \\
\hline GAPDH & ATC TTC CAG GAG CGA GAT & GGA GGC ATT GCT GAT GAT \\
\hline ALP & GTA TGAG AGT GAC GAG AA & AAT AGG TAG TCC ACA TTG T \\
\hline RUNX2 & AGC AGC ACT CCA TAT CTC T & TTC CAT CAG CGT CAA CAC \\
\hline COL1A2 & GTGGCAGTGATGGAAGTG & CACCAGTAAGGCCGTTG \\
\hline OPN & ACG CCG ACC AAG GAAAAC TC & GTC CAT AAA CCA CAC TAT CAC CTC G \\
\hline BGLAP & GCA GAG TCC AGC AAA GGT G & CCA GCC ATT GAT ACA GGT AGC \\
\hline GREM1 & GAG AAG ACG ACG AGA GTA AGG AA & CCA ACC AGT AGC AGA TGA ACA G \\
\hline NOG & CAG CAC TAT CTC CAC ATC CG & CAG CAG CGT CTC GTT CAG \\
\hline CHRD & GCC TCC GCT TCT CTA TCT & AAC AGG ACA CTG CCA TTG \\
\hline
\end{tabular}

Table 4. Overview of antibodies used to detect BMP antagonists in human IVD cells.

\begin{tabular}{|c|c|c|c|c|c|}
\hline Protein & Type and Class & Host Species & Dilution & Catalog Number & Company \\
\hline \multicolumn{6}{|c|}{ Primary Antibodies } \\
\hline Chordin & polyclonal, IgG & goat & $1: 200$ & $\begin{array}{l}\text { chordin }(\mathrm{N}-20) \text { : } \\
\text { sc-18265 }\end{array}$ & Santa Cruz \\
\hline Gremlin 1 & polyclonal, IgG & rabbit & $1: 200$ & sc-28873 & Santa Cruz \\
\hline Noggin & monoclonal, IgG2b & mouse & $1: 200$ & SAB3300029 & Sigma-Aldrich \\
\hline \multicolumn{6}{|c|}{ Secondary Antibodies } \\
\hline 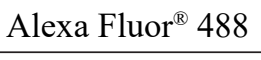 & polyclonal, IgG & goat anti-rabbit & $1: 200$ & A-11008 & Fisher Thermo Scientific \\
\hline Alexa Fluor ${ }^{\circledR} 555$ & polyclonal, IgG2b & goat anti-mouse & $1: 200$ & A-21147 & Fisher Thermo Scientific \\
\hline Alexa Fluor ${ }^{\circledR} 555$ & polyclonal, IgG & rabbit anti-goat & $1: 200$ & A-21431 & Fisher Thermo Scientific \\
\hline
\end{tabular}

and analysed with immunocytochemistry staining. Alternatively, the IVD cells were stored in PBS at $4{ }^{\circ} \mathrm{C}$ until further analysis. The cells were permeabilised with $100 \%$ methanol for 2 min, blocked with $10 \%$ FBS for $1 \mathrm{~h}$ and subsequently incubated overnight at $4{ }^{\circ} \mathrm{C}$ with the primary human antibodies against GREM1, NOG and CHRD $(1 \mu \mathrm{g} / \mathrm{mL})$ diluted in PBS $+0.5 \%$ bovine serum albumin (BSA, Sigma-Aldrich). The IVD cells were either subjected to a double labelling with NOG and GREM1 or single staining with CHRD. After thoroughly washing with PBS, incubation was conducted with the appropriate secondary antibody (Table 4 ) for $1 \mathrm{~h}$. The coverslips were mounted in SlowFade ${ }^{\circledR}$ gold antifade reagent with 4',6-diamidino-2-phenylindole (DAPI, Thermo Fisher Scientific) and the antibodies binding was visualised with a confocal laser scanning microscope (cLSM710, Carl Zeiss, Jena, Germany) with a $40 \times$ magnification immersed in oil.

\section{Conditioned medium and quantification of BMP antagonists by ELISA}

In order to generate the conditioned medium, AFC and NPC (passage one) were encapsulated in $1.2 \%$ alginate beads ( 4 millions $/ \mathrm{mL}$ ), transferred to 12 -well plates ( 6 beads/ well) and cultured for $4 \mathrm{~d}$ in the proliferation medium. The medium was filtered, centrifuged at $1000 \times g$ for $20 \mathrm{~min}$ and the supernatant was collected and stored at $-20^{\circ} \mathrm{C}$. The secreted BMP antagonists were measured in the collected medium using the human GREM1, NOG and CHRD detection kits (Clone Cloud-Clone corp., SEC128Hu, SEC130Mi and SEC126Hu, respectively, Houston, TX, USA) following the manufacturer's instructions.

\section{Alkaline phosphatase (ALP) activity}

After $21 \mathrm{~d}$ of osteogenic differentiation, the MSC layers were washed with tris-buffered saline, lysed using CelLytic (Sigma-Aldrich) and homogenised by sonication $(2 \times 7 \mathrm{~s})$. ALP was determined using the phosphatase assay kit (Sigma-Aldrich) with the instructions of the manufacturer. Briefly, the cells were transferred into 96-well plates and incubated with the p-nitrophenylphosphatase substrate at $37{ }^{\circ} \mathrm{C}$. The reaction was stopped after $30 \mathrm{~min}$ and the formed complex was measured at $405 \mathrm{~nm}$ on a microplate reader (SpectraMax M5, Bucher Biotec, Basel, Switzerland).

To assess the effect of detected concentrations (by ELISA assay) of IVD cells' secreted BMP antagonists on osteogenic differentiation, MSC were cultured for $7 \mathrm{~d}$ in osteogenic medium supplemented with recombinant GREM1 (2 ng/mL, Peprotech) and NOG (1 ng/mL) either alone or in combination and harvested for ALP activity. Positive and negative groups (MSC cultured in osteogenic medium and basal medium, respectively) were included as controls. 
Histology of mineralised matrix

The mineralised matrix in MSC was detected using alizarin red staining. The cell layer was fixed in $4 \%$ formaldehyde solution, rinsed with distilled water and subsequently exposed to $2 \%$ alizarin red solution (Sigma-Aldrich) for $45 \mathrm{~min}$. The alizarin red staining was released from the cell layer by addition of $10 \%$ cetylpyridinium chloride solution (Sigma-Aldrich) into the wells and incubation for $1 \mathrm{~h}$ while vigorously shacked. The samples were diluted 10-fold, transferred to 96-wells and subsequently the absorbance was measured at $570 \mathrm{~nm}$ with an ELISA reader (SpectraMax M5).

\section{XTT assay}

IVD cells (and MSC) were seeded in 96-well plates at a density of $2 \times 10^{3}$ cells/well and grown in the proliferation medium supplemented with L51P at concentrations of $0,10,25,50,100,250,500$ and 1,000 ng/mL. On day three, the XTT assay (Cell Proliferation kit II, Roche Diagnostics, Rotkreuz, Switzerland) was performed to measure cells viability, according to the manufacturer's recommendations. Briefly, the cells were incubated with $50 \mu \mathrm{L}$ XTT labelling mixture/well in a humidified atmosphere $\left(5 \% \mathrm{CO}_{2}, 37^{\circ} \mathrm{C}\right)$ for $3 \mathrm{~h}$. The absorbance was measured at $490 \mathrm{~nm}$ (SpectraMax M5).

\section{Statistics}

Differences in the ELISA, ALP activity and levels of transcripts were evaluated by Student's $t$-test; differences in the alizarin red staining and XTT by one-way ANOVA with Bonferroni's post-hoc test after testing the data for normal distribution, using GraphPad Prism (version 6.0h for Mac OS; GraphPad Software Inc., La Jolla, CA USA). $p<0.05$ was considered significant.

\section{Results}

\section{Endogenous disc-derived BMP antagonists}

To investigate the endogenous expression of major BMP antagonists by IVD cells, transcripts and protein levels of GREM1, NOG and CHRD were determined. Gene expression analysis revealed expression of major BMP antagonists by both AFC and NPC (Fig. 2a), with abundance in NPC, although not significant $(p=0.42$, $p=0.65$, and $p=0.72$ for GREM 1 , NOG and CHRD, respectively). Similar results were observed with immunocytochemistry: IVD cells stained positive for GREM1 and NOG with an intense staining detected in NPC (Fig. 2c). CHRD immunocytochemistry staining revealed a nuclear localisation and was equally detected in both
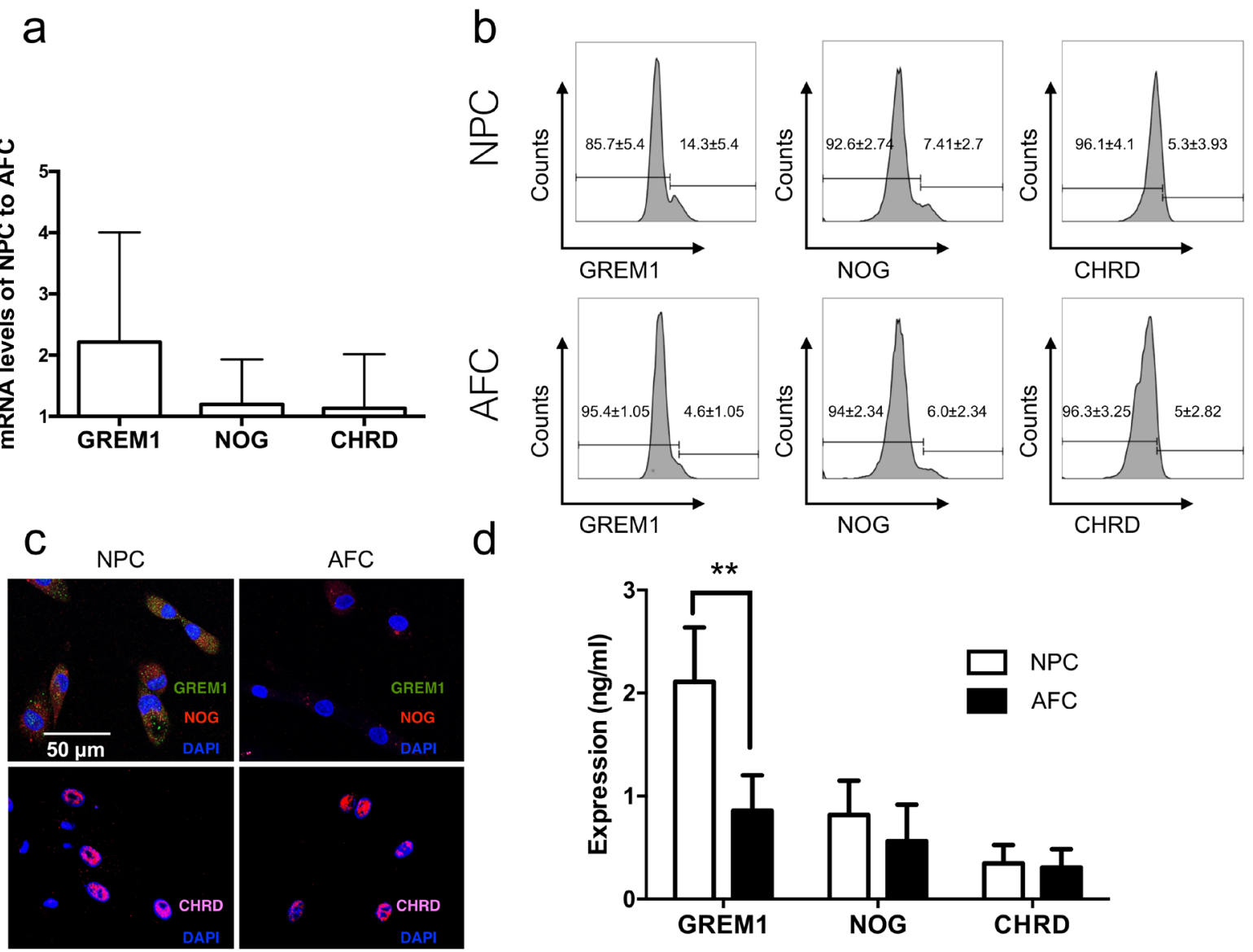

Fig. 2. The expression of endogenous bone morphogenetic proteins (BMP) antagonists by intervertebral disc cells (IVD). The expression of major BMP antagonists, i.e. Gremlin1, Noggin and Chordin was assessed in passage one nucleus pulposus cells (NPC) and annulus fibrosus cells (AFC) by (a) real-time quantitative PCR, (b) flow cytometry (intracellular staining and compared to the isotype controls), (c) immunocytochemistry and (d) ELISA (conditioned medium). An abundance of the BMP antagonists was detected by NPC. Values are expressed as means $\pm \operatorname{SD}(n=5)$. 

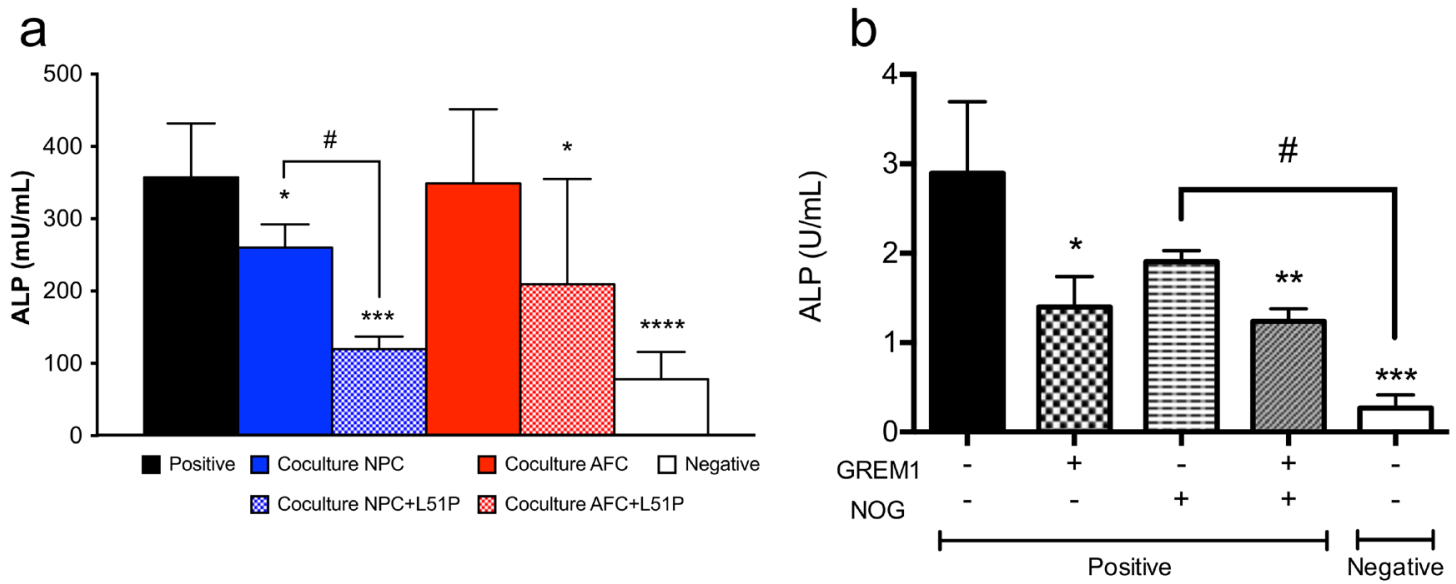

Fig. 3. The expression of alkaline phosphatase (ALP) activity in MSC. (a) MSC were cultured in osteogenic medium (positive control), coculture with nucleus pulposus cells (NPC) and annulus fibrosus cells (AFC) with and without L51P and cultured in basal medium (without osteogenic factors, negative control) for $21 \mathrm{~d}$. The ALP activity decreased in MSC in the presence of NPC and addition of L51P to the cocultures resulted in a pronounced decrease of ALP. Values are represented as means $\pm \operatorname{SD}(n=11) .{ }^{*} p<0.05, * * p<0.01,{ }^{* * *} p<0.001,{ }^{* * * *} p<0.0001$ compared to the positive control group. ${ }^{\#} p<0.05$ compared to coculture with NPC or AFC. (b) MSC were cultured in osteogenic medium supplemented with recombinant Gremlin $1(2 \mathrm{ng} / \mathrm{mL})$ and Noggin $(1 \mathrm{ng} / \mathrm{mL})$ for $7 \mathrm{~d}$. Positive control group was MSC in osteogenic medium and negative control represented MSC cultured in basal medium. Gremlin1 either alone or in combination with Noggin reduced the ALP activity of MSC. ${ }^{*} p<0.05,{ }^{* *} p<0.01$, $* * * p<0.001$ compared to the positive control group. ${ }^{*} p<0.05$ compared to negative control group.
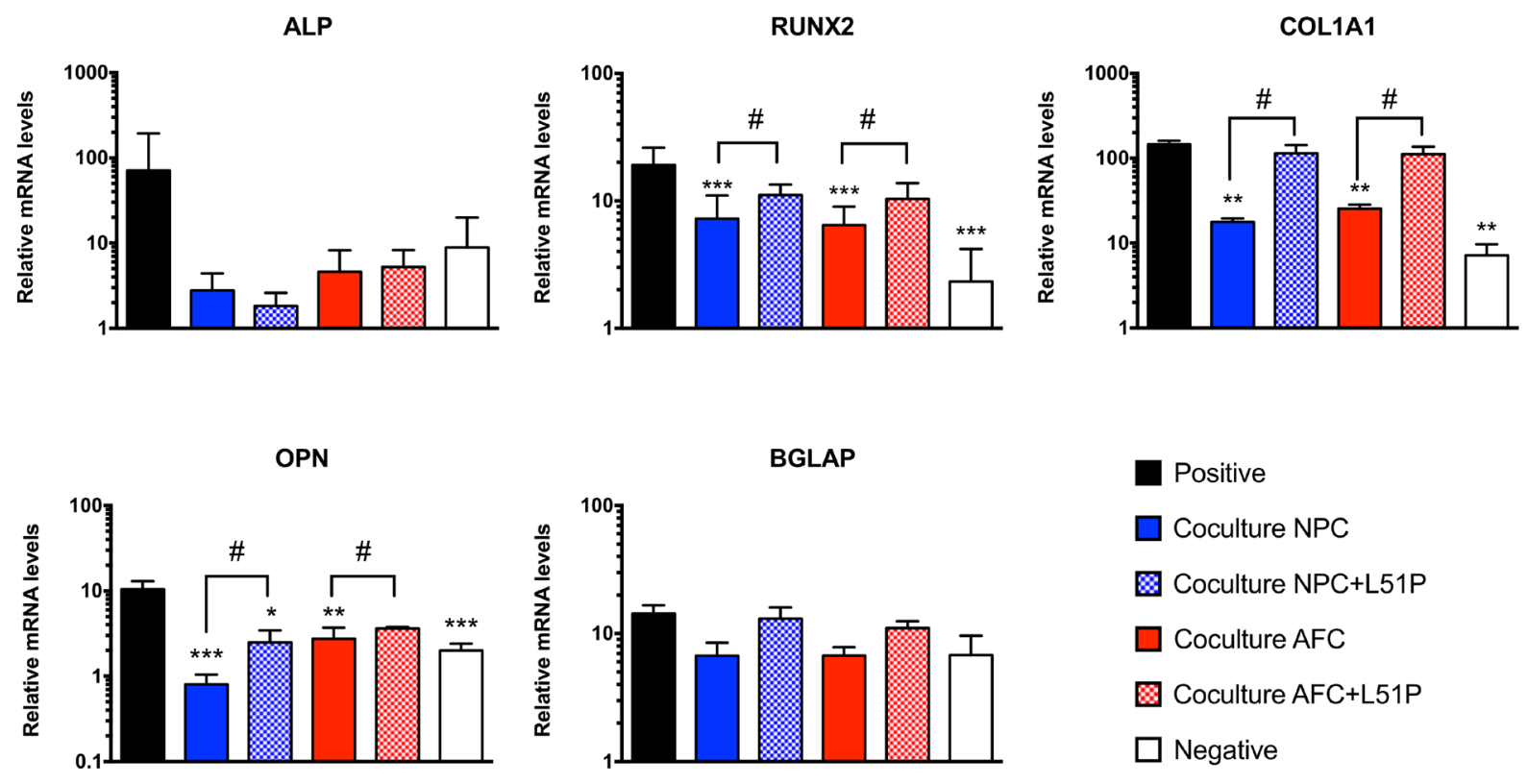

Fig. 4. Gene expression of bone-related markers, i.e. alkaline phosphatase (ALP), runt-related transcription factor 2 (RUNX2), alpha-2 chain of collagen type I (COL1A2), osteopontin (OPN) and osteocalcin (BGLAP) in MSC. MSC were cultured in osteogenic medium (positive control), coculture with nucleus pulposus cells (NPC) and annulus fibrosus cells (AFC) with and without L51P and cultured in basal medium (without osteogenic factors, negative control). A general reduction of bone-related markers was observed in MSC, when cocultured with NPC and AFC, and L51P increased the expression of RUNX2, COL1A2 and OPN to levels similar to positive control group. ALP was reduced when L51P was added to the cocultures with NPC. Values are expressed as means \pm SD $(n=6) .{ }^{*} p<0.05,{ }^{* *} p<0.01,{ }^{* * *} p<0.001$ compared to the positive control group. ${ }^{*} p<0.05$ compared to culture with NPC or AFC. 
IVD cells (Fig. 2c). By flow cytometry, variable protein levels of intracellular BMP antagonists were detectable in permeabilised AFC and NPC, resulting more abundant in NPC (Fig. 2b). The fraction of positive NPC expressing GREM1, NOG and CHRD accounted for $14.3 \pm 5.39 \%$, $7.41 \pm 2.72 \%$ and $5.3 \pm 3.93 \%$ (values presented as mean $\pm \mathrm{SD}$ ), respectively. The ratios of NPC to AFC positive for GREM1, NOG and CHRD accounted for $2.97 \pm 0.65 \%$, $1.37 \pm 0.51 \%$ and $1.02 \pm 0.76 \%$, respectively. The BMP antagonists were detectable in the conditioned medium with levels between $0.30 \pm 0.17$ and $2.10 \pm 0.52 \mathrm{ng} / \mathrm{mL}$. An abundance in GREM1 was observed in NPC ( $p=0.0022$, Fig. 2d). The ratios of NPC to AFC for GREM1, NOG and CHRD levels were $2.90 \pm 1.66,1.96 \pm 1.46$ and $1.35 \pm 0.87$, respectively.

\section{ALP activity}

After $21 \mathrm{~d}$ of osteogenic differentiation, ALP activity was measured in MSC cocultured with IVD cells in osteogenic medium and in basal medium groups. ALP activity in the osteogenic differentiation medium (positive control) accounted for $373.1 \pm 67.3 \mathrm{mU} / \mathrm{mL}$ and increased significantly as compared to MSC cultured in the basal medium (negative control $77.6 \pm 41.5 \mathrm{mU} /$ $\mathrm{mL}, \mathrm{p}<0.0001$ ) (Fig. 3a). Coculture of MSC with NPC resulted in a significant decrease of ALP activity $(p=0.03)$ and coculture of MSC with AFC did not differ from the positive control group. It was noted that L51P added to the cocultures caused a general reduction in ALP activity in all experimental groups as compared to the positive control group ( $p=0.0003$ in NPC and $p=0.015$ in AFC, respectively). In addition, cocultures of MSC and NPC with L51P resulted in a decrease of ALP activity as compared to coculture of MSC with NPC alone ( $p=0.024)$.

Recombinant GREM1 and NOG $(2 \mathrm{ng} / \mathrm{mL}$ and $1 \mathrm{ng} /$ $\mathrm{mL}$, respectively, concentrations as detected by ELISA assay in IVD cells) added to the cultures of MSC, alone or in combinations, significantly reduced ALP activity as compared to positive control group ( $p=0.010$ and $p=0.005$, respectively, Fig. 3b). However, NOG $(1 \mathrm{ng} / \mathrm{mL})$ alone did not decrease ALP activity of $\operatorname{MSC}(p=0.131)$.

\section{Gene expression}

Similarly to ALP protein level, ALP transcript level was higher in positive control and decreased in coculture of MSC with either NPC or AFC, to levels comparable to negative control (Fig. 4). Addition of L51P, in MSC cocultured with NPC, reduced ALP, although not significantly $(p=0.96)$. Similar result was observed in coculture of MSC with AFC. Relative gene expression of bone-related markers showed higher expression in positive control than in negative control. Gene expression of RUNX2, OPN and BGLAP in MSC cocultured with IVD cells was comparable to negative control. Addition of L51P to the cocultures of MSC with IVD cells resulted in a significant increase, to levels comparable to positive control, of RUNX2 ( $p=0.033$ for NPC and $p=0.009$ for $\mathrm{AFC}), \mathrm{OPN}(p=0.035$ for NPC and $p=0.001$ for AFC) and COL1A2 ( $p=0.026$ for NPC and $p=0.027$ for AFC) as compared to L51P-untreated cocultures.

\section{L51P and proliferation}

To exclude the possibility that either a cytotoxic effect and/or inhibition of proliferation induced by L51P may contribute to the alteration of IVD cells' phenotype and interact with MSC differentiation, an XTT assay was performed. Up to a concentration of $1,000 \mathrm{ng} / \mathrm{mL}$ no significant change in the number of viable IVD cells was observed (Fig. 5), suggesting that L51P is not cytotoxic and does not interfere with cell proliferation and metabolic activity. Similarly, L51P up to $1,000 \mathrm{ng} / \mathrm{mL}$ did not induce any cytotoxic effect on MSC (data not shown).

\section{Histology of mineralised matrix}

After three weeks of osteogenic induction in osteogenic differentiation medium (positive control), the MSC deposited an extensive mineralised matrix, as demonstrated by an intense alizarin red staining (Fig. 6a). However, MSC cultured in the basal medium (negative control) were negative for alizarin red and no calcium deposition was observed. Coculture of MSC with either NPC or AFC resulted in a strong reduction of mineralisation, with results comparable to the negative control ( $p>0.99$, Fig. 6b). The addition of L51P to the cocultures of MSC with NPC and AFC reversed the inhibitory effect of IVD cells and resulted in an increased calcium deposition $(p=0.0002$ and $p=0.0041$ in NPC and AFC), with results comparable to the positive control group $(p=0.37$ and $p>0.99$ in NPC and $\mathrm{AFC}$, respectively).

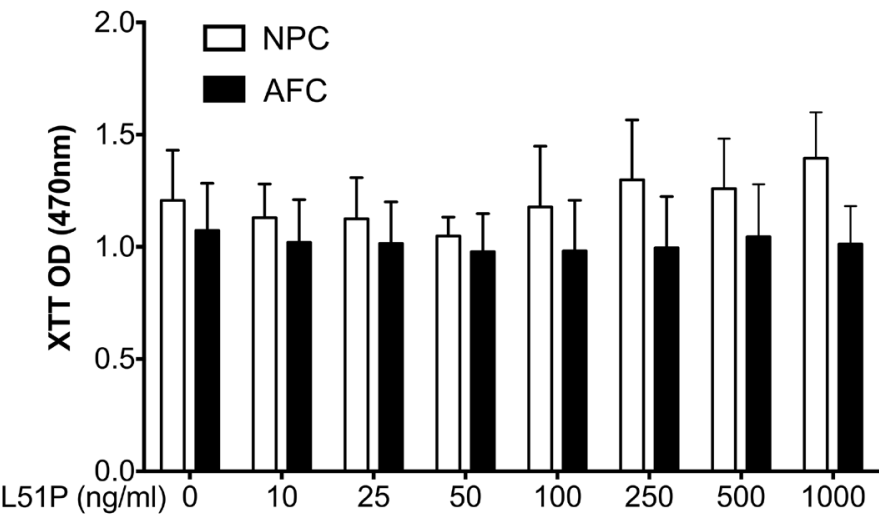

Fig. 5. Effect of L51P on the intervertebral disc cells metabolic activity. L51P added to the culture of nucleus pulposus cells (NPC) and annulus fibrosus cells (AFC) for $3 \mathrm{~d}$ did not affect the number of viable intervertebral disc cells as detected by XTT assay. Values are represented as means $\pm \mathrm{SD}(n=5)$. 
a
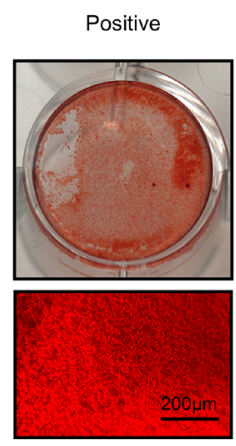

Coculture NPC
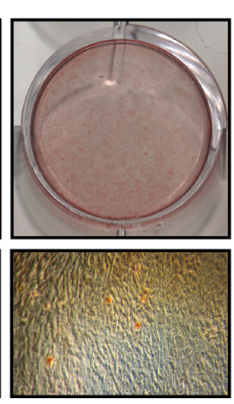

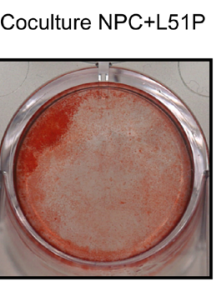

Coculture AFC
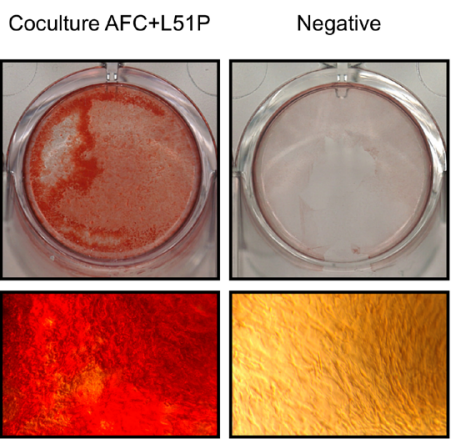

b

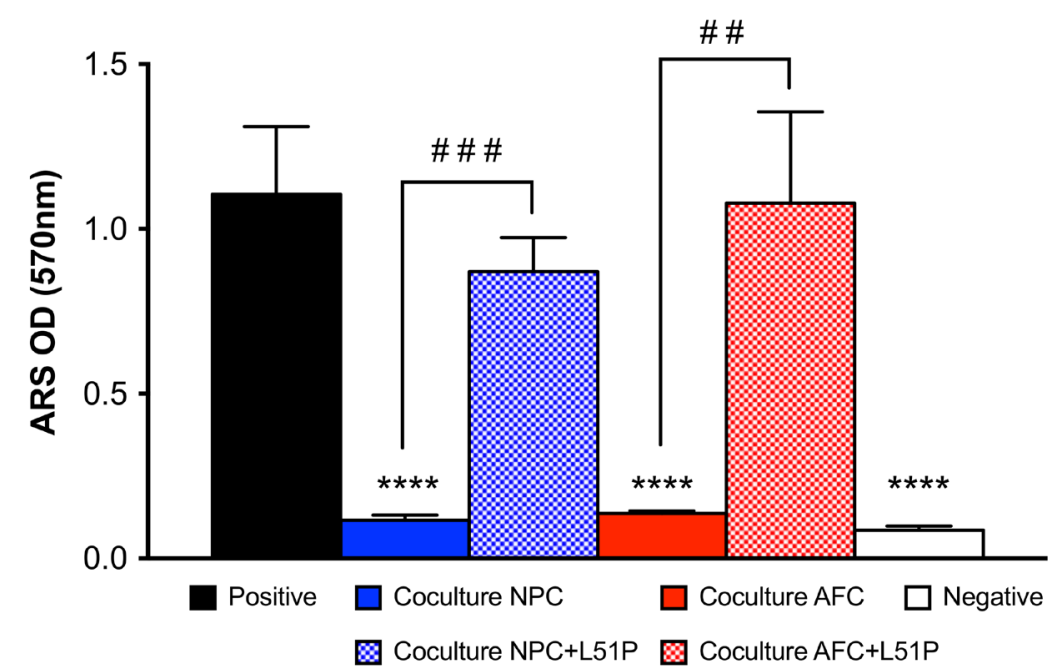

Fig. 6. Osteogenesis of bone marrow-derived mesenchymal stromal cells. MSC were cultured in osteogenic medium (positive control), cocultured with nucleus pulsposus cells (NPC) and annulus fibrosus cells (AFC) with and without L51P or cultured in basal medium (without osteogenic factors, negative control). (a) Macroscopic and microscopic images of osteogenesis (alizarin red staining) and (b) the corresponding quantification. The osteogenic differentiation of MSC was potentially altered by NPC and AFC with results similar to the negative control group. However, addition of L51P restored mineralisation to levels similar to positive control ( $p=0.15$ in coculture with NPC and $p=0.90$ in coculture with AFC). Values are shown as means $\pm \operatorname{SD}(n=4) . * p<0.05, * * \mathrm{p}<0.01$, ${ }^{* * *} p<0.001,{ }^{* * * *} p<0.0001$ compared to the positive control group. ${ }^{\#} p<0.05,{ }^{\#} \mathrm{p}<0.05,{ }^{\# \#} p<0.01$ compared to coculture with NPC or AFC.

\section{Discussion}

Spinal interbody fusion, although being the gold standard treatment for many spinal disorders, results in a nonunion rate of up to $30 \%$ of the cases (Watkins et al., 2014). Clinical observations suggested that the presence of remaining IVD tissues during spinal fusion surgery might hamper the ossification process of spinal vertebras, resulting in a delayed and incomplete interbody fusion. Along with this observation, an experimental study performed on porcine animal model showed a fusion rate of only $10 \%$ when the autograft applied in the disc space was mixed with NP tissue, while the bridging rate increased to $70 \%$ when a pure autograft was used (Li et $a l ., 2002)$. We previously reported that IVD cells hinder the osteogenic differentiation of MSC in an in vitro coculture system (Chan et al., 2015). However, the exact mechanism by which the disc cells inhibit bone formation remains not fully understood. RhBMP2 has been used in the clinics to accelerate and augment bone regeneration in bone fractures, long bones non-union and spinal fusion. Although promising clinical trials, the growth factor has to be applied at levels that exceed those of naturally occurring BMP2 present in $1,000 \mathrm{~kg}$ of bone tissue to induce sufficient bone formation (Urist et al., 1979; Govender et al., 2002; Boden et al., 2002). This raises the concerns regarding costs, safety issues and also complications associated with rhBMP2 leading to ectopic bone and cyst formation (Tannoury and An, 2014; Zara et al., 2011).

While the importance of BMP antagonists, including NOG, GREM1, CHRD and twisted gastrulation was previously described in joint development, bone remodelling and fracture healing (Wijgerde et al., 2005; Khokha et al., 2003; Brunet et al., 1998; Zakin and De Robertis, 2004; Abe2006; Fisher and Halpern, 1999; Wu et al., 2003; Dean et al., 2010; Yoshimura et al., 2001), their contributions in IVD is not yet fully understood.

Within this study, we aimed to investigate the role of BMP signalling within the spine microenvironment in spinal fusion by determining the expression of endogenous 
disc cells-derived BMP antagonists. We could confirm that IVD cells secrete the major BMP antagonists, namely NOG, GREM1 and CHRD with abundance in NPC with up to $2 \mathrm{ng} / \mathrm{mL}$, a concentration shown to prevent the osteogenic differentiation potential of MSC (our study) and osteoblasts differentiation (Wu et al., 2003). CHRD synthesised by IVD cells accumulates in the vertebral body of mouse embryo (Zakin et al., 2010). In addition, a recent study reported a loss of CHRD expression with degeneration of the IVD, suggesting the potential use of CHRD as a marker for healthy disc phenotype (Minogue et al., 2008).

It is of interest that GREM1 was also found differently regulated in our donor-matched NP versus AF samples at the transcript and protein level. GREM1 was found significantly dysregulated in a recent microarray study comparing the transcriptome of AF tissues between degenerated and non-degenerated patients (Kazezian et $a l ., 2015)$. This indicates that GREM1 could be regulated by increased disc degeneration. However, this study did not compare NP and AF expression of the same donor.

BMP antagonists could be determinant for healing, incomplete or even failure of bone regeneration. Several attempts to enhance bone healing by suppression of BMP antagonists were described. Wan et al. showed that NOG suppression by small interfering RNA (siRNA) in MC3T3-T1 cells and mice calvarial osteoblasts enhanced the cells osteogenic differentiation potential. In addition, NOG siRNA-transfected osteoblasts, that were implemented in murine calvarial critical size defect, accelerated bone regeneration as compared to control osteoblasts (Wan et al., 2007). Similarly, CHRD knockdown by siRNA accelerates the differentiation of MSC towards the osteoblastic lineage and leads to increased deposition of minerals in vitro (Kwong et al., 2008). In addition, in mice, conditional deletion of GREM1 under the control of the bone-specific osteocalcin promoter enhanced osteoblastic activity and led to increased trabecular bone volume (Gazzerro et al., 2007).

To further understand the role of BMP signalling in spinal fusion, we aimed to investigate the contribution of the IVD cells' secreted BMP antagonists for spinal fusion and inhibition of osteogenic differentiation of osteoprecursor cells. Therefore, we targeted the BMP antagonists by addition of the BMP2 variant L51P to the cocultures of MSC and IVD cells. We showed that L51P could salvage the osteogenic differentiation of MSC in the presence of IVD cells as evidenced by transcripts and protein levels. To address the regulation of osteoblast formation, we determined the transcription factors RUNX2, ALP, COL1A2, osteopontin (OPN) and osteocalcin (BGLAP). The latter two have been commonly used as early and late markers of osteogenic differentiation. Our data revealed an increase of bonerelated markers of MSC in the presence of L51P suggesting their differentiation towards the osteoblastic lineage. Albers et al. (2012) reported an enhanced BGLAP gene expression in culture of primary murine osteoblasts with L51P. Similarly, Khattab et al. (2014) detected an increase of the osteoblast-specific transcription factor in the MC3T3 osteoblastic cell line by addition of L51P. However, we found that L51P decreased the ALP gene expression of human MSC and these results were confirmed on the protein level by measuring the ALP activity after $21 \mathrm{~d}$ of culture. This observation could be attributed to the fact that ALP is an early marker of osteogenic differentiation. We found that in culture the ALP activity of MSC increases with a peak observed after $10 \mathrm{~d}$ and thereafter declines to the baseline levels by 21-28 d (data not shown). Along with this finding, it was previously reported that L51P decreases the ALP activity of terminally differentiated murine calvarial osteoblasts after $3 \mathrm{~d}$ of culture (Albers et al., 2012). The precise mechanism of inhibition of ALP activity by L51P remains not perceptible and needs to be further elucidated.

To address the inhibitory effect of BMP antagonists on osteogenesis, we investigated by histology the ability of MSC to deposit calcium, as an outcome for bone formation in vitro. We found that IVD cells strongly inhibit the mineralisation of MSC, while L51P abolishes the IVD-mediated inhibition of osteogenic differentiation and leads to an intensive mineralisation potential. These finding confirmed that the IVD's secreted BMP antagonists are responsible for inhibition of osteogenic differentiation of bone precursor cells.

Current attempts to improve spinal fusion include the local administration of high concentrations of rhBMP2 or rhBMP7 in the IVD space after disc removal in combination with cages (Carragee et al., 2011; Simmonds et al., 2013). The large demand of the growth factors is probably required to compensate for the presence of BMP antagonists secreted by the IVD cells. Recently, intradiscal application of rhBMP7 was administrated at a dose of $250 \mu \mathrm{g}$ per single canine disc and revealed, however, no IVD regeneration. Instead extensive bone formation was noticed (Willems et al., 2015).

The inhibition of BMP antagonists represents a promising alternative to enhance bone regeneration. Sebald et al. (2012) showed that a combination of BMP2 and L51P (at $1 \mu \mathrm{g}$ per scaffold) loaded $\beta$-tricalcium phosphate ceramics better promoted bone formation compared to BMP2, only in a critical size femur defect of rat model. These data suggested that L51P inhibits the action of BMP antagonists to regulate the signalling mediated by BMP2, without the requirement of adding large amounts of exogenous growth factors. Taking all together, the inhibition of BMP antagonists by L51P may result in a more efficient and physiological BMP signalling, rather than delivery of exogenous osteoinductive factors, such as BMP2. Therefore, this strategy represents an attractive treatment to induce bone healing.

To the best of our knowledge, this is the first study reporting a protein-based approach to enhance osteoinduction of osteoprogenitor cells in the presence of IVD cells via inhibition of BMP antagonists. Besides understanding basic mechanisms of spinal non-union after discectomy, the current study suggests the potential use of factors antagonising disc-mediated BMP inhibitors, such as L51P, in order to increase bone regeneration in the disc niche.

Future research should investigate into the central mediator(s) of bone formation in spinal fusion surgery. 
Recently, it has been shown that BMP9-induced osteogenic differentiation of MSC is independent on NOG (Wang et al., 2013). Further, the role of the cartilaginous endplate cells in spinal fusion should be elucidated.

\section{Conclusion}

This study confirms a significant inhibition of osteogenic differentiation in osteoprogenitor cells in the presence of IVD cells and provides similar evidences in spinal nonunion. The mechanism is most likely due to an alteration of BMP signalling cascade caused by the IVD cells-mediated BMP antagonists. Furthermore, this study demonstrates that BMP signalling plays an important role in regulating bone formation and that antagonising the BMP inhibitors with L51P may improve the bioavailability of endogenous BMP to increase and accelerate bone formation. Future long-term animal studies will determine the suitability of the application of L51P as a therapeutic target to enhance bone regeneration in spinal fusion.

\section{Acknowledgments}

We thank Eva Roth for technical assistance, Silvia Dolder for inputs with the XTT assay. Walter Sebald, Department of Physiological Chemistry, University of Würzburg and Hansjörg Sebald, Spine Center Thun, Switzerland, provided the BMP2 variant L51P. The imaging part of this study was performed on equipment supported by the Microscopy Imaging Center (MIC), University of Bern, Switzerland. The FACS work was done in the FACS-Lab core facility of the University of Bern. The project was supported by the funds "Teaching and Research" of the Lindenhofstiftung \#15-05F, by Hansjörg Wyss and by the Hansjörg Wyss Medical foundation, USA.

\section{References}

Abe E (2006) Function of BMPs and BMP antagonists in adult bone. Ann N Y Acad Sci 1068: 41-53.

Albers CE, Hofstetter W, Sebald HJ, Sebald W, Siebenrock KA, Klenke FM (2012) L51P - ABMP2 variant with osteoinductive activity via inhibition of Noggin. Bone 51: 401-406.

Balagué F, Mannion AF, Pellisé F, Cedraschi C (2012) Non-specific low back pain. Lancet 379: 482-491.

Boden SD, Kang J, Sandhu H, Heller JG (2002) Use of recombinant human bone morphogenetic protein-2 to achieve posterolateral lumbar spine fusion in humans: a prospective, randomised clinical pilot trial: 2002 Volvo award in clinical studies. Spine (Phila Pa 1976). 27: 26622673.

Brunet LJ, McMahon JA, McMahon AP, Harland RM (1998) Noggin, cartilage morphogenesis, and joint formation in the mammalian skeleton. Science 280: 1455 1457.

Carragee EJ, Hurwitz EL, Weiner BK (2011) A critical review of recombinant human bone morphogenetic protein-2 trials in spinal surgery: emerging safety concerns and lessons learned. Spine J 11: 471-491.

Carragee EJ, Baker RM, Benzel EC, Bigos SJ, Cheng I, Corbin TP, Deyo RA, Hurwitz EL, Jarvik JG, Kang JD, Lurie JD, Mroz TE, Oner FC, Peul WC, Rainville J, Ratliff JK, Rihn JA, Rothman DJ, Schoene ML, Spengler DM, Weiner BK (2012) A biologic without guidelines: the YODA project and the future of bone morphogenetic protein-2 research. Spine J 12: 877-880.

Chan SC, Tekari A, Benneker LM, Heini PF, Gantenbein B (2015) Osteogenic differentiation of bone marrow stromal cells is hindered by the presence of intervertebral disc cells. Arthritis Res Ther 18: 29.

Dagenais S, Caro J, Haldeman S (2008) A systematic review of low back pain cost of illness studies in the United States and internationally. Spine J 8: 8-20.

Dean DB, Watson JT, Jin W, Peters C, Enders JT, Chen A, Moed BR, Zhang Z (2010) Distinct functionalities of bone morphogenetic protein antagonists during fracture healing in mice. J Anat 216: 625-630.

Fisher S, Halpern ME (1999) Patterning the zebrafish axial skeleton requires early chordin function. Nat Genet 23: 442-446.

Flagler DJ, Huang C-Y, Yuan T-Y, Lu Z, Cheung HS, Gu WY (2009) Intracellular flow cytometric measurement of extracellular matrix components in porcine intervertebral disc cells. Cell Mol Bioeng 2: 264-273.

Friedlaender GE, Perry CR, Cole JD, Cook SD, Cierny G, Muschler GF, Zych GA, Calhoun JH, LaForte AJ, Yin S (2001) Osteogenic protein-1 (bone morphogenetic protein-7) in the treatment of tibial nonunions. J Bone Joint Surg Am 83-A Suppl 1: S151-S158.

Gazzerro E, Smerdel-Ramoya A, Zanotti S, Stadmeyer L, Durant D, Economides AN, Canalis E (2007) Conditional deletion of gremlin causes a transient increase in bone formation and bone mass. J Biol Chem 282: 3154931557.

Govender S, Csimma C, Genant HK, Valentin-Opran A, Amit Y, Arbel R, Aro H, Atar D, Bishay M, Börner MG, Chiron P, Choong P, Cinats J, Courtenay B, Feibel R, Geulette B, Gravel C, Haas N, Raschke M, Hammacher E, van der Velde D, Hardy P, Holt M, Josten C, Ketterl RL, Lindeque B, Lob G, Mathevon H, McCoy G, Marsh D, Miller R, Munting E, Oevre S, Nordsletten L, Patel A, Pohl A, Rennie W, Reynders P, Rommens PM, Rondia J, Rossouw WC, Daneel PJ, Ruff S, Rüter A, Santavirta S, Schildhauer TA, Gekle C, Schnettler R, Segal D, Seiler H, Snowdowne RB, Stapert J, Taglang G, Verdonk R, Vogels L, Weckbach A, Wentzensen A, Wisniewski T, BMP-2 evaluation in surgery for tibial trauma (BESTT) study group (2002) Recombinant human bone morphogenetic protein-2 for treatment of open tibial fractures: a prospective, controlled, randomised study of four hundred and fifty patients. J Bone Joint Surg Am 84-A Suppl 1: 2123-2134.

Haid RW, Branch CL, Alexander JT, Burkus JK (2004) Posterior lumbar interbody fusion using recombinant human bone morphogenetic protein type 2 with cylindrical interbody cages. Spine J 4: 527-538

Haque T, Hamade F, Alam N, Kotsiopriftis M, Lauzier D, St-Arnaud R, Hamdy RC (2008) Characterizing the 
BMP pathway in a wild type mouse model of distraction osteogenesis. Bone 42: 1144-1153.

Hoy D, March L, Brooks P, Blyth F, Woolf A, Bain C, Williams G, Smith E, Vos T, Barendregt J, Murray C, Burstein R, Buchbinder R (2014) The global burden of low back pain: estimates from the global burden of disease 2010 study. Ann Rheum Dis 73: 968-974.

Kazezian Z, Gawri R, Haglund L, Ouellet J, Mwale F, Tarrant F, O’Gaora P, Pandit A, Alini M, Grad S (2015) Gene expression profiling identifies interferon signalling molecules and IGFBP3 in human degenerative annulus fibrosus. Sci Rep 5: 15662.

Keller S, Nickel J, Zhang J-L, Sebald W, Mueller TD (2004) Molecular recognition of BMP-2 and BMP receptor IA. Nat Struct Mol Biol 11: 481.

Khattab HM, Ono M, Sonoyama W, Oida Y, Shinkawa S, Yoshioka Y, Maekawa K, Tabata Y, Sugama K, Sebald W, Kuboki T (2014) The BMP2 antagonist inhibitor L51P enhances the osteogenic potential of BMP2 by simultaneous and delayed synergism. Bone 69: 165-173.

Khokha MK, Hsu D, Brunet LJ, Dionne MS, Harland RM (2003) Gremlin is the BMP antagonist required for maintenance of Shh and Fgf signals during limb patterning. Nat Genet 34: 303-307.

Kloen P, Lauzier D, Hamdy RC (2012) Co-expression of BMPs and BMP-inhibitors in human fractures and nonunions. Bone 51: 59-68.

Kwong FN, Richardson SM, Evans CH (2008) Chordin knockdown enhances the osteogenic differentiation of human mesenchymal stem cells. Arthritis Res Ther 10: R65.

Lee CS, Hwang CJ, Lee DH, Kim YT, Lee HS (2011) Fusion rates of instrumented lumbar spinal arthrodesis according to surgical approach: a systematic review of randomised trials. Clin Orthop Surg 3: 39-47.

Lee JT, Cheung KM, Leung VY (2015) Systematic study of cell isolation from bovine nucleus pulposus: improving cell yield and experiment reliability. J Orthop Res 33: 1743-1755.

Li H, Zou X, Laursen M, Egund N, Lind M, Bünger $C$ (2002) The influence of intervertebral disc tissue on anterior spinal interbody fusion: an experimental study on pigs. Eur Spine J 11: 476-481.

Livak KJ, Schmittgen TD (2001) Analysis of relative gene expression data using real-time quantitative PCR and the 2(-Delta Delta C(T)) method. Methods 25: 402-408.

Malter AD, McNeney B, Loeser JD, Deyo RA (1998) 5 -year reoperation rates after different types of lumbar spine surgery. Spine 23: 814-820.

May RD, Tekari A, Frauchiger DA, Krismer A, Benneker LM, Gantenbein B (2017) Efficient non-viral transfection of primary intervertebral disc cells by electroporation for tissue engineering application. Tissue Eng Part C Methods 23: 30-37

McAfee PC, Lee GA, Fedder IL, Cunningham BW (2002) Anterior BAK instrumentation and fusion: complete versus partial discectomy. Clin Orthop Relat Res 394: 55 63.

McMahon JA, Takada S, Zimmerman LB, Fan CM, Harland RM, McMahon AP (1998) Noggin-mediated antagonism of BMP signaling is required for growth and patterning of the neural tube and somite. Genes Dev 12: 1438-1452.

Minogue BM, AJ F, Hoyland JA. (2008) The expression of chordin in the intervertebral disc. World forum for spine research: the intervertebral disc. Kyoto Japan.

Osterman H, Sund R, Seitsalo S, Keskimäki I (2003) Risk of multiple reoperations after lumbar discectomy: a population-based study. Spine 28: 621-627.

Rahman MS, Akhtar N, Jamil HM, Banik RS, Asaduzzaman SM (2015) TGF- $\beta$ /BMP signaling and other molecular events: regulation of osteoblastogenesis and bone formation. Bone Res 3: 15005.

Salazar VS, Gamer LW, Rosen V (2016) BMP signalling in skeletal development, disease and repair. Nat Rev Endocrinol 12: 203-221.

Sebald HJ, Klenke FM, Siegrist M, Albers CE, Sebald W, Hofstetter W (2012) Inhibition of endogenous antagonists with an engineered BMP-2 variant increases BMP-2 efficacy in rat femoral defect healing. Acta Biomater 8: 3816-3820.

Simmonds MC, Brown JV, Heirs MK, Higgins JP, Mannion RJ, Rodgers MA, Stewart LA (2013) Safety and effectiveness of recombinant human bone morphogenetic protein-2 for spinal fusion: a meta-analysis of individualparticipant data. Ann Intern Med 158: 877-889.

Solchaga LA, Penick K, Porter JD, Goldberg VM, Caplan AI, Welter JF (2005) FGF-2 enhances the mitotic and chondrogenic potentials of human adult bone marrowderived mesenchymal stem cells. J Cell Physiol 203: 398409.

Stafford DA, Brunet LJ, Khokha MK, Economides AN, Harland RM (2011) Cooperative activity of noggin and gremlin 1 in axial skeleton development. Development 138: $1005-1014$.

Tannoury CA, An HS (2014) Complications with the use of bone morphogenetic protein 2 (BMP-2) in spine surgery. Spine J 14: 552-559.

Tsuji K, Bandyopadhyay A, Harfe BD, Cox K, Kakar S, Gerstenfeld L, Einhorn T, Tabin CJ, Rosen V (2006) BMP2 activity, although dispensable for bone formation, is required for the initiation of fracture healing. Nat Genet 38: 1424-1429.

Turner JA, Ersek M, Herron L, Haselkorn J, Kent D, Ciol MA, Deyo R (1992) Patient outcomes after lumbar spinal fusions. JAMA 268: 907-911.

Urist MR, Mikulski A, Lietze A (1979) Solubilised and insolubilised bone morphogenetic protein. Proc Natl Acad Sci U S A 76: 1828-1832.

Walsh DW, Godson C, Brazil DP, Martin F (2010) Extracellular BMP-antagonist regulation in development and disease: tied up in knots. Trends Cell Biol 20: 244-256.

Wan DC, Pomerantz JH, Brunet LJ, Kim JB, Chou YF, Wu BM, Harland R, Blau HM, Longaker MT (2007) Noggin suppression enhances in vitro osteogenesis and accelerates in vivo bone formation. J Biol Chem 282: 26450-26459.

Wang Y, Hong S, Li M, Zhang J, Bi Y, He Y, Liu X, Nan G, Su Y, Zhu G, Li R, Zhang W, Wang J, Zhang H, Kong Y, Shui W, Wu N, He Y, Chen X, Luu HH, Haydon RC, Shi 
LL, He TC, Qin J (2013) Noggin resistance contributes to the potent osteogenic capability of BMP9 in mesenchymal stem cells. J Orthop Res 31: 1796-1803.

Watkins R, Watkins R, Hanna R (2014) Non-union rate with stand-alone lateral lumbar interbody fusion. Medicine (Baltimore) 93: e275.

Wijgerde M, Karp S, McMahon J, McMahon AP (2005) Noggin antagonism of BMP4 signaling controls development of the axial skeleton in the mouse. Dev Biol 286: 149-157.

Willems N, Bach FC, Plomp SG, van Rijen MH, Wolfswinkel J, Grinwis GC, Bos C, Strijkers GJ, Dhert WJ, Meij BP, Creemers LB, Tryfonidou MA (2015) Intradiscal application of rhBMP-7 does not induce regeneration in a canine model of spontaneous intervertebral disc degeneration. Arthritis Res Ther 17: 137.

Wu M, Chen G, Li Y-P (2016) TGF- $\beta$ and BMP signaling in osteoblast, skeletal development, and bone formation, homeostasis and disease. Bone Research 4: 16009.

Wu XB, Li Y, Schneider A, Yu W, Rajendren G, Iqbal J, Yamamoto M, Alam M, Brunet LJ, Blair HC, Zaidi M, Abe E (2003) Impaired osteoblastic differentiation, reduced bone formation, and severe osteoporosis in nogginoverexpressing mice. J Clin Invest 112: 924-934.

Yanagita M (2005) BMP antagonists: their roles in development and involvement in pathophysiology. Cytokine Growth Factor Rev 16: 309-317.

Yoshimura Y, Nomura S, Kawasaki S, Tsutsumimoto T, Shimizu T, Takaoka K (2001) Colocalisation of noggin and bone morphogenetic protein-4 during fracture healing. J Bone Miner Res 16: 876-884.

Zakin L, De Robertis EM (2004) Inactivation of mouse twisted gastrulation reveals its role in promoting Bmp4 activity during forebrain development. Development 131: 413-424.

Zakin L, Chang EY, Plouhinec JL, De Robertis EM (2010) Crossveinless-2 is required for the relocalisation of Chordin protein within the vertebral field in mouse embryos. Dev Biol 347: 204-215.

Zara JN, Siu RK, Zhang X, Shen J, Ngo R, Lee M, Li W, Chiang M, Chung J, Kwak J, Wu BM, Ting K, Soo C (2011) High doses of bone morphogenetic protein 2 induce structurally abnormal bone and inflammation in vivo. Tissue Eng Part A 17: 1389-1399.

\section{Discussion with Reviewers}

Laura Creemers: Are there any synthetic inhibitors of the antagonists that could be used to single out the actual mechanism of L51P induced restoration of mineralisation? Authors: Besides L51P, we are not aware of other synthetic molecules that are commercially available and could be used with the aim to inhibit BMP antagonists. Instead, molecule-based techniques, such as suppression by small interfering RNA (siRNA), cognate antibody or conditional deletion could be used to address the effect of individual BMP antagonists (Ghadakzadeh et al., 2016). For instance, Noggin siRNA-transfected osteoblasts, that were implemented into calvarial critical size defect, showed enhanced bone regeneration as compared to control osteoblasts (Wan et al., 2007). Same results, using a similar knock-down approach, were achieved for adipose-derived MSCs (Fan et al., 2013). Similarly, blocking of Chordin by siRNA enhanced osteogenic differentiation of human mesenchymal stem cells and induced extracellular mineral deposition (Kwong et al., 2008).

Lisbet Haglund: What delivery system would the authors foresee being used for L51P clinical application?

Authors: Ideally, the scaffold applied for bone regeneration should provide biocompatibility, well-defined porosity, biodegradation rate and importantly the capability to control sustained growth factor release. Calcium phosphate-based materials, such as hydroxyapatite and tricalcium phosphate, represent well-established bone substitutes for orthopaedic clinical applications. However, to overcome the insufficient retention of the growth factors within the carrier biomaterial, high concentrations of the proteins are generally required, with adverse side effects including heterotopic ossification. Efficient and controlled delivery of growth factors from the carrier critically depends on their release kinetics.

We propose L51P immobilised on $\beta$-tricalcium phosphate $(\beta$-TCP) ceramics with a calcium phosphate co-precipitation technique previously described (Choy et al., 2014; Wernike et al., 2010) for spinal fusion surgery, as well as for reconstruction of large bone defects. This modified form of local and sustained delivery system might allow a long-term release of the biologically active L51P into the surrounding extracellular matrix, possibly by cellmediated mechanism, such as the resorption activity of bone marrow cells differentiated into osteoclasts. Further, in vivo studies are needed to address the suitability of the $\beta$-TCP delivery system and the action of L51P on bone regeneration.

In the case of partial discectomy for spinal fusion, L51P could be bound to the hydrogel-like system that enables slow growth factor release, such as a thermoreversible hydrogel (TR-HG), based on a modified polysaccharide with a thermo-reversible polyamide [poly(N-isopropylacrylamide)]. Such a hydrogel would have the advantage of easy delivery to the site by injection through a syringe and by fast gelation.

Lisbet Haglund: What is the half-life of L51P in culture media and, if known, in vivo?

Authors: We did not estimate the half-life of L51P in culture media, however, in an in vitro protein release assay, L51P was stable over a culture period of three weeks and was accumulated into the supernatant as detected by a BMP2 ELISA assay (Sebald et al., 2012). L51P loaded $\beta$-tricalcium phosphate ceramics with $1 \mu \mathrm{g}$ or $10 \mu \mathrm{g}$ per scaffold resulted in a burst release of $60 \%$ of the total protein amount within the first $24 \mathrm{~h}$ with no difference in the relative protein release kinetics whether $1 \mu \mathrm{g}$ or $10 \mu \mathrm{g}$ was adsorbed. Further animal studies will determine the stability of L51P applied.

Lisbet Haglund: Does L51P affect viability and metabolic activity of connective tissue cells? 
Authors: Based on our results and previous studies (Albers et al., 2012), L51P added to the cultures does not affect the cell viability nor induce a cytotoxic effect on human intervertebral disc cells, human bone marrowderived mesenchymal stromal cells and murine calvarial osteoblasts.

\section{Additional References}

Choy J, Albers CE, Siebenrock KA, Dolder S, Hofstetter W, Klenke FM (2014) Incorporation of RANKL promotes osteoclast formation and osteoclast activity on $\beta$-TCP ceramics. Bone 69: 80-88.
Fan J, Park H, Tan S, Lee M (2013) Enhanced osteogenesis of adipose derived stem cells with Noggin suppression and delivery of BMP-2. PLoS ONE 8: e72474.

Ghadakzadeh S, Mekhail M, Hamdy R, Tabrizian M. (2016) siRNA-mediated Noggin inhibition enhances osteogenesis and mineralization. Bone Abstracts. DOI:10.1530/boneabs.5.LB15

Wernike E, Hofstetter W, Liu Y, Wu G, Sebald HJ, Wismeijer D, Hunziker EB, Siebenrock KA, Klenke FM (2010) Long-term cell-mediated protein release from calcium phosphate ceramics. J Biomed Mater Res A 92: 463-474.

Editor's note: The Scientific Editor responsible for this paper was Brian Johnstone. 